\title{
Depression and Chronic Liver Diseases: Are There Shared Underlying Mechanisms?
}

\author{
Xiaoqin Huang ${ }^{1 *}$, Xiaoyun Liu $^{1}$ and Yongqiang Yu${ }^{2 *}$ \\ 1 Department of Psychiatry, The First Affiliated Hospital of Anhui Medical University, Hefei, China, ${ }^{2}$ Department of Radiology, \\ The First Affiliated Hospital of Anhui Medical University, Hefei, China
}

The occurrence of depression is higher in patients with chronic liver disease (CLD) than that in the general population. The mechanism described in previous studies mainly focused on inflammation and stress, which not only exists in CLD, but also emerges in common chronic diseases, leaving the specific mechanism unknown. This review was to summarize the prevalence and risk factors of depression in CLD including chronic hepatitis B, chronic hepatitis, alcoholic liver disease, and non-alcoholic fatty liver disease, and to point out the possible underlying mechanism of this potential link. Clarifying the origins of this common comorbidity (depression and CLD) may provide more information to understand both diseases.

\section{OPEN ACCESS}

Edited by:

Hermona Soreq,

Hebrew University of Jerusalem, Israel

Reviewed by:

Annie Andrieux

Commissariat à l'Energie Atomique et aux Energies Alternatives, France Ari Meerson, Migal - Galilee Technology Center

Israel

Chanan Meydan, Tel Aviv Sourasky Medical Center, Israel

*Correspondence: Xiaoqin Huang xiaoqin.ahmu@gmail.com Yongqiang $\mathrm{Yu}$ cjr.yuyongqiang@vip.163.com

Received: 22 January 2017 Accepted: 20 April 2017 Published: 08 May 2017

Citation:

Huang X, Liu X and Yu Y (2017)

Depression and Chronic Liver

Diseases: Are There Shared Underlying Mechanisms?

Front. Mol. Neurosci. 10:134 doi: 10.3389/fnmol.2017.00134
Keywords: chronic liver disease (CLD), depression, hepatitis, non-alcoholic fatty liver disease (NAFLD), alcoholic liver disease (ALD)

\section{INTRODUCTION}

Chronic liver disease is the progressive destruction and regeneration of the liver parenchyma leading to fibrosis and cirrhosis (normally lasts 6 months). The etiologic agents of CLD include hepatotropic viruses (HBV and HCV), fatty liver, alcohol, autoimmune hepatitis, etc. The mortality of CLD patients remains high not only due to irreversible cirrhosis, but also multiple complications such as HCC and mental disease, especially depression.

Depression, also named MDD, MDE, or clinical depression, is a mental disorder characterized by a pervasive and persistent low mood that is accompanied by low self-esteem and by a loss of interest or pleasure in normally enjoyable activities. CLD has been long recognized and associated with depression (Gutteling et al., 2006; Patten et al., 2008). Clinical studies have shown that some patients with CLD have more severe depressive tendencies (Mullish et al., 2014) than healthy ones. However, the underlying mechanisms of this association remain largely unknown, since previous studies used different diagnostic criteria to evaluate depression in chronic diseases. For

Abbreviations: 5-HTR1A, serotonin 1A receptor; 5-HTTLPR, serotonin transporter gene-linked polymorphic region; ACTH, adrenocorticotropic hormone; ALD, alcoholic liver disease; BDI-sf, Beck Depression Inventory Short Form; BDNF, brain-derived neurotrophic factor; BMI, body mass index; $\mathrm{CH}-\mathrm{B}$, chronic hepatitis $\mathrm{B}$; $\mathrm{CH}-\mathrm{C}$, chronic hepatitis C; CLD, chronic liver disease; CNS, central nervous system; DSM, Diagnostic and Statistical Manual of Mental Disorders; GAF, Global Assessment of Functioning; GGT, $\gamma$-glutamyl transpeptidase; GHQ, General Health Questionnaire; HBsAg, hepatitis B surface antigen; HBV, hepatitis B virus; HCC, hepatocellular carcinoma; HCV, hepatitis C virus; HPA, hypothalamic-pituitary-adrenal; HRQOL, health-related quality of life; HSC, hepatic stellate cell; hs-CRP, high-sensitivity C-reactive protein; IDO, indoleamine-2,3-dioxygenase; IFN, Interferon; IL, interleukin; KCs, kupffer cells; LT, liver transplantation; MDD, major depressive disorder; MDE, major depressive episode; NAFLD, non-alcoholic fatty liver disease; NASH, non-alcoholic steatohepatitis; NLRs, NOD-like receptors; NLRP3, NLRs family pyrin domain containing 3; NOD, nucleotide-binding oligomerization domain; PET, positron emission tomography; RBV, ribavirin; TRP, tryptophan. 
example, Ismail et al. (2007) used standard psychiatric interview (Schedules of Clinical Assessment in Neuropsychiatry) to diagnose MDD in patients with diabetes and their first foot ulcer. In a cross-sectional study, Popović et al. (2015) used the Hamilton depression rating scale (HDRS) in patients with CLD and found that depression was present in $62.9 \%$ of them. In addition, a number of studies on CLD have instead used self-report questionnaires (Bellentani et al., 1994; Dwight et al., 2000; Dan et al., 2006).

Here, we summarize studies that used both conventional diagnostic criteria and questionnaires to identify depression in CLD [especially in viral hepatitis, ALD, and NAFLD], to point out the potential link between two diseases, which may provide more information to understand both diseases.

\section{THE LINK BETWEEN DEPRESSION AND CLD}

\section{Chronic Hepatitis B}

Chronic HBV infection is defined as the persistence of $\mathrm{HBsAg}$ and serum HBV-DNA levels detectable for at least 6 months. Globally, CH-B affects approximately 400 million people worldwide and contributes to more than one million deaths annually of liver disease (Lavanchy, 2004). CH-B has become one of the major causes of chronic hepatitis, cirrhosis, and HCC worldwide. For patients with active viral replication, cirrhosis will be observed in $15-20 \%$ of patients within 5 years. Among patients with cirrhosis, the disease may progress, and the incidence of HCC is significantly elevated. $70-90 \%$ of patients with HCC have cirrhosis (Karayiannis and Thomas, 2005). It has been found that hepatitis B has a markedly negative impact on HRQOL, both in terms of physical function and mental health.

In 1984, Lok and his colleagues firstly studied the psychosocial effect of chronic HBV infection in 40 British carriers by using their own questionnaire. Thirty-six of these patients (90\%) considered themselves that their physical and psychological health including sexual, work, social, and family attitudes, were negatively affected. Thirty-four of them experienced depression, 22 felt isolated especially initially, and 15 had feelings of guilt. In addition, 3 had sought, and 4 considered seeking psychiatric help (Lok et al., 1985). Although the sample size was small, this study indicates a potential relationship between CLD and depression. Consisting with this finding, a couple of years later, Kunkel et al. (2000) evaluated 50 Korean immigrants who had $\mathrm{CH}-\mathrm{B}$ or were healthy carriers for the HBV in terms of the relationships between their depression scores, psychosocial stressors, social support, and biological markers of dysfunction. All patients completed the BDI-sf (Hojat et al., 1986), a self-report BDI screening test for depression that is scored as an index of severity of depressed mood. The average total BDI-sf score of them was 5.4 (BDI-sf scores $>5$ means mild to severe depression). Twenty-three patients (46\%) endorsed depressive symptomatology. Interestingly, higher depression scores were significantly associated with transaminase elevations both before and after BDI-sf administration, which discloses a more concrete relationship between depression and CLD than
Lok's study, regardless their similar sample size and absence of controls. This limitation was much improved by a larger study from Weinstein et al. (2011) in which the prevalence of depression was compared among patients with $\mathrm{CH}-\mathrm{B}, \mathrm{CH}-\mathrm{C}$, and NAFLD based on patient self-report and confirmed by examining history of prescription medication. In this study, a total number of $190 \mathrm{CH}-\mathrm{B}$ were enrolled, and only 7 (3.7\%) had a diagnosis of depression (Weinstein et al., 2011). The low morbidity of depression in this study may be attributed to the missing self-report by the patients who had mild or moderate depression.

Actually, not only $\mathrm{CH}-\mathrm{B}$ patients, but also HBsAg carriers need psychological therapies (Table 1). Atesci et al. (2005) studied the psychiatric morbidity in a homogeneous group of asymptomatic HBV carriers by using the BDI, DSM IV Axis I (psychiatric disorders) and Axis V (global functioning assessment). They found that HBV carriers were more likely to have psychiatric disorders than healthy subjects (30.2\% vs. $11.6 \%)$. Furthermore, carriers had significantly higher depression scores and lower GAF scores than comparison subjects. The high rates of psychiatric disorder in HBV carriers might be related to the frightening and potentially stigmatizing nature of hepatitis $B$ (Atesci et al., 2005). However, a Turkish study examining the effect of HBV infection on the psychological state of children showed no significant difference between asymptomatic carrier patients and control children with respect to depression scores. The different result may be explained by: (i) the absence of symptoms and insufficient information about children's status; (ii) the society protecting children from stigmatization (Arslan et al., 2003). These possible explanations suggest that children are a special group and are not appropriate to compare with adults. Nevertheless, another study showed that the prevalence of depression increased significantly among CH-B patients in Iran (29.3\%) after excluding inactive HBsAg carriers (10.0\%), whereas it was similar between inactive HBsAg carriers and healthy participants (10.0\% vs. $11.3 \%)$ (Mirabdolhagh Hazaveh et al., 2015). In contrast, Altindag et al. (2009) reported that $20 \%$ of $\mathrm{CH}-\mathrm{B}$ patients were suffering from severe depression (score $\geq 17$ ), and this number fell to 13.3 and $3.3 \%$ in HBsAg carriers and healthy controls, respectively. In addition, HRQOL scores in asymptomatic carriers were similar to those of non-cirrhotic $\mathrm{CH}-\mathrm{B}$ patients, but worse than those of healthy controls (Altindag et al., 2009).

\section{Chronic Hepatitis C}

Chronic hepatitis $\mathrm{C}$ is a worldwide health problem that affects approximately 170 million people globally (3\%) (Lavanchy, 2011; Mohd Hanafiah et al., 2013). CH-C is now the most common cause of end-stage liver failure and the leading indication for liver transplant in the developed countries. Emerging evidence suggests that psychiatric problems, particularly depression, frequently occur in chronic infection with $\mathrm{HCV}$ and during antiviral treatment. As in other chronic medical illnesses, the presence of depression symptoms in $\mathrm{CH}-\mathrm{C}$ is critical because they exhibit an adverse effect on the course of illness, with amplification of physical symptoms, functional impairment, and decreased 
TABLE 1 | The prevalence of depression in patients with $\mathrm{CH}-\mathrm{B}$.

\begin{tabular}{|c|c|c|c|}
\hline Patients & Methods & Results & Reference \\
\hline 40 British HBV carriers & Questionnaire & $\begin{array}{l}34 \text { patients experienced depression } \\
22 \text { felt isolated } \\
15 \text { felt guilty } \\
3 \text { had sought and } 4 \text { considered seeking psychiatric help }\end{array}$ & Lok et al., 1985 \\
\hline $\begin{array}{l}50 \text { Korean } \mathrm{CH} \text {-B Healthy } \\
\text { HBV carriers }\end{array}$ & Clinical interview BDI-sf & $\begin{array}{l}23 \text { patients ( } 46 \% \text { ) endorsed depressive } \\
\text { symptomatology }\end{array}$ & Kunkel et al., 2000 \\
\hline $\begin{array}{l}20 \mathrm{CH}-\mathrm{B} \text { children patients } \\
20 \text { asymptomatic carriers } \\
43 \text { healthy control }\end{array}$ & CDI & $\begin{array}{l}\text { No difference between asymptomatic carrier and } \\
\text { control group children with respect to depression } \\
\text { scores }\end{array}$ & Arslan et al., 2003 \\
\hline $\begin{array}{l}43 \text { asymptomatic carriers } \\
43 \text { healthy controls }\end{array}$ & $\begin{array}{l}\text { BDI-sf Structured Clinical } \\
\text { Interview for DSM-IV GAF Scale }\end{array}$ & $\begin{array}{l}\text { HBV carriers were more likely to have psychiatric } \\
\text { disorders than comparison subjects ( } 30.2 \% \text { vs. } 11.6 \%) \\
\text { Carriers had significantly higher depression scores and } \\
\text { lower GAF scores than comparison subjects }\end{array}$ & Atesci et al., 2005 \\
\hline $\begin{array}{l}30 \mathrm{CH}-\mathrm{B} \text { patients } \\
30 \text { inactive HBsAg carriers } \\
30 \text { healthy controls }\end{array}$ & BDI-sf & $\begin{array}{l}20 \% \text { of } \mathrm{CH}-\mathrm{B} \text { patients were suffering from severe } \\
\text { depression, } 13.3 \% \text { in } \mathrm{HBsAg} \text { carriers, and } 3.3 \% \text { in } \\
\text { healthy controls }\end{array}$ & Altindag et al., 2009 \\
\hline $190 \mathrm{CH}-\mathrm{B}$ patients & $\begin{array}{l}\text { Self-report Examine history of } \\
\text { prescription medication }\end{array}$ & $3.7 \% \mathrm{CH}-\mathrm{B}$ patients had a diagnosis of depression & Weinstein et al., 2011 \\
\hline $\begin{array}{l}81 \text { Iran } \mathrm{CH}-\mathrm{B} \text { patients } \\
80 \text { healthy controls }\end{array}$ & HAMD-17 & $\begin{array}{l}\text { Inactive HBsAg carriers and } \mathrm{CH} \text {-B patients-excluding } \\
\text { inactive } \mathrm{HBsAg} \text { carriers-differed significantly in their } \\
\text { prevalence of depression ( } 10.0 \% \text { vs. } 29.3 \%)\end{array}$ & Mirabdolhagh Hazaveh et al., 2015 \\
\hline
\end{tabular}

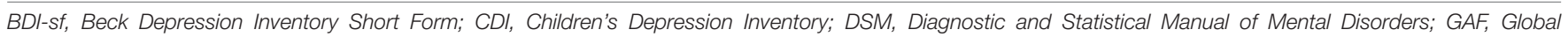
Assessment of Functioning; 17-item Hamilton Depression Rating Scale (HAMD-17); HRQOL, health-related quality of life.

compliance of treatment and quality of life (Dwight et al., 2000).

High proportion of patients with $\mathrm{CH}-\mathrm{C}$ had been diagnosed as having depression (Schaefer et al., 2012) (Table 2). For example, Dwight et al. (2000) evaluated $50 \mathrm{CH}-\mathrm{C}$ patients using structured psychiatric interviews and standardized rating instruments, and found that $14(28 \%)$ of patients had current depressive disorders, and their disability and fatigue were more closely related to depression severity than to hepatic disease severity. In another large study of $22341 \mathrm{HCV}$-infected veterans and 43267 healthy controls, el-Serag et al. (2002) reported that patients were more likely to have depressive disorders than controls (49.5\% vs. $39.1 \%)$. A recent study assessing the association between different types of CLD with depression in a population-based cohort showed that depression was strongly associated with CH-C (Lee et al., 2013). Furthermore, Golden et al. (2005) studied $90 \mathrm{CH}-\mathrm{C}$ participants and demonstrated a $28 \% 1$-month prevalence of depression, and $72 \%$ of whom were previously unidentified. Carta et al. (2007) provided the evidence that $\mathrm{CH}-\mathrm{C}$ was associated with MDD, independent of IFN- $\alpha$ treatment $(32.6 \%)$.

\section{Alcoholic Liver Disease}

Chronic excessive alcohol use is a common global health care concern and is associated with significant high morbidity and mortality. Approximately 20 to $30 \%$ of primary LTs are performed for patients with ALD (Erim et al., 2007; Adam et al., 2012; Stepanova et al., 2014). Alcohol use disorders are the second common indication for LTs in the US and Europe (Burra et al., 2010; Rice et al., 2013; Singal et al., 2013). The term "ALD" comprises a spectrum of pathologic characteristics including isolated steatosis, alcoholic steatohepatitis and established cirrhosis. Within this spectrum, varying degrees of inflammation, ballooning degeneration and hepatocyte necrosis, cholestasis, and fibrosis may be encountered (Sakhuja, 2014).

Some researchers proposed that alcohol use may lead to depression symptoms as well as an increased risk of parasuicide and suicide (Gilman and Abraham, 2001; Cargiulo, 2007). In contrast, others have found that depression may escalate alcohol use (Gilman and Abraham, 2001; Crum et al., 2005). Interestingly, a recent study showed that depression increased the risk of alcohol dependence only in men (Bulloch et al., 2012). These findings suggest that ALD may be associated with mental morbidity as well. Unsurprisingly, further studies reported that ALD was associated with depressive symptoms, particularly in the elderly (Cargiulo, 2007; Seitz and Stickel, 2007; O'Shea et al., 2010). Given the aging of the US population, it is increasingly significant to evaluate the relationship between ALD and depression. In a cohort of patients with ALD including both cirrhotic and noncirrhotic, Ewusi-Mensah et al. (1983) showed that $40 \%$ of patients had psychiatric disorders, although there was no direct correlation between the degree of ALD and the likelihood of depression. In LT recipients with ALD, the psychologic stress from end-stage liver disease (Singh et al., 1997; DiMartini et al., 2011), surgical evaluation, and candidacy for LT (Dew et al., 1998), and subsequent surgery are risk factors in the development of depression (Corruble et al., 2011; DiMartini et al., 2011). Regarding the association between ALD and depression, further research should investigate the bidirectional relationship between them.

\section{Non-alcoholic Fatty Liver Disease}

Non-alcoholic fatty liver disease is the hepatic independent manifestation of the metabolic syndrome. The spectrum of 
TABLE 2 | The prevalence of depression in patients with $\mathrm{CH}-\mathrm{C}$.

\begin{tabular}{|c|c|c|c|}
\hline Patients & Methods & Results & Reference \\
\hline $50 \mathrm{CH}-\mathrm{C}$ patients & $\begin{array}{l}\text { Structured psychiatric interview } \\
\text { DSM IV BDI-sf21 }\end{array}$ & $14(28 \%)$ of patients had current depressive disorders & Dwight et al., 2000 \\
\hline $\begin{array}{l}22341 \mathrm{CH}-\mathrm{C} \text { veteran patients } \\
43267 \text { controls }\end{array}$ & ICD-9 CM & $\begin{array}{l}\mathrm{CH}-\mathrm{C} \text { patients were more likely to have depressive disorders than } \\
\text { healthy controls }(49.5 \% \text { vs. } 39.1 \%)\end{array}$ & el-Serag et al., 2002 \\
\hline $90 \mathrm{CH}-\mathrm{C}$ patients & $\begin{array}{l}\text { Structured Clinical Interview for } \\
\text { DSM-IV Axis I Disorders }\end{array}$ & $\begin{array}{l}\text { There was a } 28 \% 1 \text {-month prevalence of depressive disorders, } 72 \% \\
\text { of whom were previously undiagnosed. }\end{array}$ & Golden et al., 2005 \\
\hline $\begin{array}{l}135 \mathrm{CH}-\mathrm{C} \text { patients, } \\
540 \text { healthy control }\end{array}$ & DSM-IV & $\begin{array}{l}\text { A significantly higher number of lifetime diagnoses of MDD among } \\
\text { patients with } \mathrm{CHC} \text { compared to controls (32.6\% vs } 12.8 \%) \\
\text { independent of IFN- } \alpha \text { treatment. }\end{array}$ & Carta et al., 2007 \\
\hline $\begin{array}{l}162 \mathrm{CH}-\mathrm{C} \text { at baseline and } \\
\text { treatment with IFN }\end{array}$ & 20-item SDS & $\begin{array}{l}\text { Compared with baseline, mean SDS index scores were significantly } \\
\text { increased by week } 4 \text { and remained elevated throughout the study. } \\
39 \% \text { of patients experienced moderate to severe depressive } \\
\text { symptoms at some point during the therapy. }\end{array}$ & Schaefer et al., 2002 \\
\hline $325 \mathrm{CH}-\mathrm{C}$ patients & MDI/DSM-IV criteria & $\begin{array}{l}19 \text { patients (6\%) had major depression at baseline and an additional } \\
114(37 \%) \text { developed depression while on HCV combination therapy. } \\
\text { Only } 36(32 \%) \text { of the } 114 \text { patients developed major depression. }\end{array}$ & Leutscher et al., 2010 \\
\hline
\end{tabular}

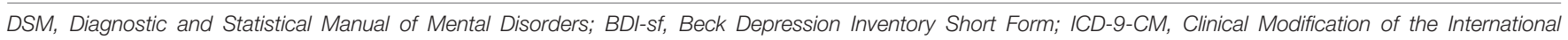
Classification of Diseases; SDS, Zung Self-Rating Depression Scale; MDI, Major Depression Inventory.

NAFLD ranges from simple steatosis through NASH and fibrosis to 'cryptogenic' cirrhosis, HCC and other complications (liver failure and gastroesophageal varices) (Clark et al., 2002; Youssef and McCullough, 2002; Hui et al., 2003). NAFLD is strongly associated with obesity and insulin resistance-related metabolic features such as type 2 diabetes mellitus, hyperlipidemia, and systemic hypertension (Wanless and Lentz, 1990; Bellentani et al., 1994; Clark et al., 2002; Charlton et al., 2011). With an aging and increasingly obese and diabetic population (Wild et al., 2004), the prevalence of NAFLD is significantly rising, leaving a public health concern among industrialized nations. Current estimates suggest that the prevalence in the general population is around one-third (Browning et al., 2004; Chitturi et al., 2004), rising in high-risk populations to as high as 70\% (Angulo, 2002; Targher et al., 2007). As a primary cause, NAFLD has become the third most common cause of LTs in the US (8.5\%) (Charlton et al., 2011).

There is growing evidence of links between NAFLD and depression. Several population-based studies have identified high prevalence of depression in patients with NAFLD. For instance, a study using a large population of CLD indicated that the prevalence of depression was significantly higher in patients with NAFLD compared with that in patients with $\mathrm{CH}-\mathrm{B}$ (27.2\% vs. 3.7\%). They also found independent predictors of depression in this cohort were the presence of hypertension, smoking, history of lung disease, being female, and non-African-American. However, its clinical features were not explicitly stated (Weinstein et al., 2011). Another small matched case-control study by Elwing et al. (2006) showed that the prevalence of lifetime MDD was higher in the NASH population than that in control subjects matched for age, gender, BMI, and waist-hip ratio. Importantly, they found that the diagnosis of MDD tended to be associated with steatosis grade, after adjusting for other clinical confounders. In accordance with this, Youssef et al. (2013) also provided evidence that psychiatric disorders were associated with histological severity of liver diseases. They assessed a cohort of 567 North American patients with biopsyproven NAFLD and demonstrated that subclinical and clinical depression were noted in 53 and $14 \%$ of NAFLD patients, respectively, Interestingly, depression was associated with more severe hepatocyte ballooning and patients with subclinical depression had a higher likelihood of having more severe portal fibrosis after adjusting for confounders (Youssef et al., 2013). These results are consistent with another recent study by Tomeno et al. (2015), in which NAFLD patients comorbid with MDD were characterized by more severe histological steatosis and higher NAFLD activity score. Moreover, serum aminotransferase, GGT, ferritin, and hs-CRP were dramatically higher in the NAFLD patients with MDD than those without MDD.

\section{THE EFFECT OF ANTIVIRAL MEDICATIONS ON LIVER AND DEPRESSION}

Depression is a condition not only associated with HCV infection, but also with pegylated IFN- $\alpha$ treatment in patients with $\mathrm{CH}$-C. IFN- $\alpha$-associated depression develops in a total of $30-70 \%$ of $\mathrm{HCV}$-infected patients during treatment, in which mild to moderate depression accounts for 45-60\%, moderate to severe depression, 15-40\%, and major depression, 15-45\% (Raison et al., 2005a,b; Schaefer et al., 2002, 2003, 2007, 2012). The prevalence of IFN- $\alpha$-associated depression is related to dosage and duration of treatment, and a previous history of psychiatric disorders (Schaefer et al., 2007; Leutscher et al., 2010). The prevalence depends on different assessment methods such as diagnostic interview, self-reports, clinical evaluation and observer-rated scales, and the severity of depression and the time of evaluation (Schaefer et al., 2012). Nevertheless, the type of IFN (pegylated or standard IFN), and combination therapy (IFN and RBV) have no significant impact on the prevalence of IFN- $\alpha$-associated depression. A recent study by Leutscher et al. 
(2010) showed that $10 \%$ of $\mathrm{CH}-\mathrm{C}$ patients treated with pegylated IFN and RBV had to prematurely withdraw from treatment, because $65 \%$ of them (most did not undergo antidepressant therapy) had developed major depression, which might adversely affect the outcome from HCV treatment. A number of earlier studies reported that anti-depressive treatment might optimize the outcome of HCV antiviral therapy, particularly by reducing the risk of early treatment discontinuation (Kraus et al., 2001; Maddock et al., 2004; Raison et al., 2005a). The recognition and treatment of pre-existing mental illness before HCV therapy yields improved tolerability and treatment response (Schaefer et al., 2007). Therefore, predicting psychiatric side effects of antivirus drugs is crucial for clinical research.

\section{RISK FACTORS OF DEPRESSION IN PATIENTS WITH CH-C}

Given that some patients are more likely to present depression during treatment with IFN- $\alpha$, researchers have increasingly focused on identifying various social, clinical and biological factors that may lead to depression symptoms (Table 3). The possibly substantial cultural differences, which exist between the societies in which the various quoted studies were conducted, might affect the risk of depression. Furthermore, stigmatization and the fact that $\mathrm{CH}-\mathrm{C}$ patients have to fight with a chronic infectious disorder for a long time increase the occurrence of depression (Golden et al., 2005; Schafer et al., 2005). A previous history of depression was also demonstrated to be a risk factor for the development of depression during antiviral therapy (Hauser et al., 2002; Gohier et al., 2003; Raison et al., 2005a), while that was not observed in Leutscher's study (Leutscher et al., 2010). Other clinical risk factors such as fatigue and sleep disturbance strikingly heralded the emergence of depression (Gohier et al., 2003; Leutscher et al., 2010). In addition, Horikawa et al. (2003) found that age was another apparent risk factor, although divergent observations in this regard have been reported previously by Hauser et al. (2002). They showed that there was no difference in age of $\mathrm{CH}-\mathrm{C}$ patients between those who became IFN-induced MDD and those who did not. Similarly, some studies have yielded conflicting data with respect to female as a risk factor for the development of IFN-associated depression. Using multivariate regression analysis, Leutscher et al. (2010) identified female as a significant independent predictor for subsequent development of major depression. This finding is similar to previous study showing the greater likelihood of female patients to develop depression during IFN- $\alpha-2 B$ and RBV treatment of CH-C (Fontana et al., 2002). However, Bonaccorso et al. (2002) found no significant gender-related differences in the effects of IFN- $\alpha$ on the development of depression.

\section{EVIDENCE FOR GENOMIC INFLUENCE IN MODULATING DEPRESSION}

Polymorphisms in specific genes encoding several key players of the serotonergic system have been shown to confer an increased risk for depression in HCV patients during IFN therapy (Capuron et al., 2003; Valentine and Meyers, 2005). Firstly, some studies have found the classical genetic risk factor for depression, the s allele of the short/long polymorphism within the 5-HTTLPR (Bull et al., 2009; Lotrich et al., 2009). Intriguingly, Pierucci-Lagha et al. (2010) investigated the functional role of these alleles (e.g., $\mathrm{L}_{\mathrm{G}} \mathrm{L}_{\mathrm{G}}, \mathrm{L}_{\mathrm{G}} \mathrm{S}$, and $\mathrm{SS}$ carriers were designated S'S' and found low expression levels) and demonstrated that in Hispanic HCV patients with IFN- $\alpha$ treatment, $S$ ' allele homozygotes showed markedly higher depression symptom scores. In contrast, among non-Hispanic Caucasians, L' allele homozygotes showed more depression symptoms than $\mathrm{S}^{\prime}$ allele carriers did (Pierucci-Lagha et al., 2010). These findings suggest that ethnicity might be associated with this classical genetic risk factor during IFN therapy. Secondly, the 5-HTR1A is one of the most abundant receptors in the hippocampus and has been previously reported in some affective disorders (Naughton et al., 2000; Hensler, 2003; Navines et al., 2003; Lopez-Figueroa et al., 2004). Kraus et al. (2007) found that homozygosity for the $\mathrm{G}$ allele of the 5-HTR1A (C1019G) polymorphism in the promoter region of the 5-HT1A receptor gene conferred a higher risk for the development of IFN-induced depression compared to carriers with at least one $\mathrm{C}$ allele. In accordance with previous study, Cozzolongo et al. (2015) demonstrated that this C-1019G polymorphism within the transcriptional control region of the 5-HTR1A gene independently predicted the incidence of IFN-induced depression in patients with $\mathrm{CH}-\mathrm{C}$. Thirdly, relevant to the metabolism of serotonin, much more attention has been paid on IDO, which breaks down TRP, the primary amino acid precursor for serotonin. Although the IDO enzyme seems to be involved in the pathophysiology of IFN-induced depression, Galvao-de Almeida et al. (2011) suggested that there was no influence of the variants in the IDO gene and the diagnosis of IFN-related depression in the Brazilian population. Interestingly, Smith et al. (2012) found that in 800 Caucasians with $\mathrm{CH}-\mathrm{C}$, a polymorphism (rs9657182) in the promoter region of the gene encoding IDO was markedly associated with moderate or severe IFN- $\alpha$-induced depression symptoms, whereas it did not predict depression in African Americans, who exhibited a significantly lower frequency of the risk allele at this locus (Smith et al., 2012). These observations confirm that ethnicity can modulate the risk for depression in $\mathrm{CH}-\mathrm{C}$ during IFN therapy again. In addition to the serotonergic system, polymorphisms in the promoter region of the IFN- $\alpha / \beta$ receptor 1 (IFNAR1) can increase the risk of developing depression in $\mathrm{HCV}$ patients who are receiving antiviral treatments (Rifai and Sabouni, 2012). Besides, a growing number of studies have also reported an association between polymorphisms in immune genes and the incidence of depression (Gochee et al., 2004; Bull et al., 2009; Lotrich et al., 2010; Su et al., 2010).

\section{SHARED PATHOLOGICAL PATHWAYS}

Although the reasons for the high prevalence of depression in patients with $\mathrm{CH}-\mathrm{C}$ are not very clear, emerging evidence has 
TABLE 3 | Potential risk factors of depression in patients with $\mathrm{CH}-\mathrm{C}$.

\begin{tabular}{|c|c|c|c|}
\hline Social factors & Sociodemographic factors & Clinical factors & Genetic factors (Polymorphisms) \\
\hline Cultural differences & Age & A previous history of depression & $5-H T T L P R$ (the s allele of the short/long \\
\hline Stigmatization & Female & Fatigue & polymorphism) 5-HTR1A (C-1019G) \\
\hline \multirow[t]{4}{*}{ Long time stress } & Ethnicity & Sleep disturbance & IDO (rs9657182) \\
\hline & & & IFNAR1 \\
\hline & & & Immune genes (IL-6, TNF- $\alpha)$ \\
\hline & & & Others (PLA2, COX2, epsilon4) \\
\hline
\end{tabular}

5-HTTLPR, the serotonin transporter gene-linked polymorphic region; 5-HTR1A, the serotonin 1A receptor; IDO, indoleamine-2,3-dioxygenase; PLA2, Phospholipase A2; COX2, cyclooxygenase 2.

supported the hypothesis that HCV directly or indirectly induces biological changes in the CNS, which may result in psychiatric symptoms. In a previous study using proton magnetic-resonance spectroscopy, Forton et al. (2001) demonstrated the elevations in basal ganglia and white matter choline/creatine ratios in patients with $\mathrm{CH}-\mathrm{C}$. Furthermore, the observation from Weissenborn et al. (2006) indicated the decreased alteration of serotonin and dopamine transporter binding in $\mathrm{CH}-\mathrm{C}$ patients with chronic fatigue and cognitive impairment, which might be associated with depression. Of note, Grover et al. (2012) provided further in vivo evidence for a neurotropic role for HCV. Using PET with a ligand for microglial/brain macrophage activation, ${ }^{11} \mathrm{C}-(\mathrm{R})-\mathrm{PK} 11195$ (PK11195) and cerebral proton magnetic resonance spectroscopy, they demonstrated that microglial activation was positively correlated with $\mathrm{HCV}$ viraemia and altered cerebral metabolism in the brains of patients with CH-C (Grover et al., 2012). Therefore, HCV may have a specific biological role in the development of depression.

Activated innate immunity and an acute-phase inflammatory response are commonly implicated in pathogenesis of CLD. Hepatic inflammation promotes the development of liver fibrosis (LF), cirrhosis and HCC, in which inflammasomes may play a key role. Inflammasomes are multi-protein complexes, which can sense endogenous and exogenous danger signals, ultimately activating the inflammatory process. Accumulating evidence supports an important role of the NOD-like receptors (NLRs) family pyrin domain containing 3 (NLRP3) inflammasome in the initiation and progression of CLD (Henao-Mejia et al., 2012; Szabo and Petrasek, 2015). A recent study showed that $\mathrm{HCV}$ RNA engagement of the NLRP3 inflammasome stimulated IL-1 $\beta$ secretion in KCs (Negash et al., 2013). In addition to viral hepatitis, Wree et al. (2014b) demonstrated the NLRP3 inflammasome was an essential contributor to LF during NASH development in mice. Furthermore, NLRP3 inflammasome activation led to hepatocyte pyroptosis, severe hepatic inflammation and HSC activation accompanied by collagen deposition in the liver (Wree et al., 2014a). Interestingly, it has also been reported the relevance of the NLRP3 inflammasome in the pathogenesis of depression (Alcocer-Gómez et al., 2014; Choi and Ryter, 2014; Zhang et al., 2015). Alcocer-Gómez observed increased gene expression of NLRP3 and caspase-1 in blood cells, and increased serum levels of IL-1 $\beta$ and IL-18 in MDD patients (Alcocer-Gómez et al., 2014). Furthermore, the
NLRP3 inflammasome was up-regulated in lipopolysaccharideinduced mice depressive-like behaviors (Zhang et al., 2014). Importantly, some drugs conferred an antidepressant effect in a model of depression by inhibiting NLRP3 inflammasome activation (Lu et al., 2014; Liu et al., 2015; Xue et al., 2015; Li et al., 2016). While the relationship of depression with CLD is complicated, shared biological mechanisms might underlie the association between depression and CLD in some individuals. The study focused on this underlying association will provide more information to understand both diseases. Overall, these findings indicate that the NLRP3 inflammasome is involved in the pathogenesis of depression and CLD, understanding its role in both diseases may build a linkage between them.

\section{MOLECULAR MECHANISMS AND TARGETS UNDERLYING A POSSIBLE CONNECTION}

All studies above mostly focused on the prevalence of depression in patients with CLD, while few studies investigated the underlying biological mechanism, especially the potential effect of HBV on brain and peripheral blood. Importantly, there are many limitations in early studies: (i) the sample size is small and there is no control; (ii) missing self-report by patients who have mild or moderate depression; (iii) the distribution of $\mathrm{HBV}$ infection worldwide varies according to geographical zone (Parkins et al., 2009). The impact of the carriage of HBV in highly epidemic $(>8 \%)$ areas such as South East Asia and Africa is greatly different from low epidemic areas $(<2 \%)$.

Recent advances have also been made to understand potential mechanisms leading to neuropsychiatric toxicity in $\mathrm{CH}-\mathrm{C}$ patients treated with IFN- $\alpha$. Numerous studies have indicated that significant alterations in serotonin, dopamine and norepinephrine neurotransmitter metabolism and activation of a pro-inflammatory cytokine network are involved in psychiatric disorders associated with IFN- $\alpha$ (Widner et al., 2000; Raison et al., 2005b; Neurauter et al., 2008; Capuron et al., 2011). Moreover, another mechanism underlying the psychiatric effects of IFN- $\alpha$ may involve alterations in neuroendocrine function. Raison et al. (2010). demonstrated that chronic exposure to IFN- $\alpha$ for 12 weeks in patients with $\mathrm{CH}-\mathrm{C}$ was associated with a flattening of the diurnal ACTH and cortisol slopes, which might contribute to the altered diurnal HPA axis activity and 
behavior found in $\mathrm{CH}-\mathrm{C}$. However, in a previous study by Wichers et al. (2007), there was no relationship between daily average salivary cortisol concentrations or the cortisol awakening response and depression in HCV patients treated with IFN- $\alpha$. In addition to neuroendocrine function, Fábregas et al. (2016) investigated whether there might be any specific alteration in plasma biomarkers associated with MD in patients with $\mathrm{CH}-\mathrm{C}$. They followed up $50 \mathrm{HCV}$-infected patients (14 of them treated with IFN), and found that the occurrence of MD increased significantly in patients during IFN treatment. Importantly, lower baseline adiponectin levels and use of IFN were associated with MD development, which indicates that adiponectin may be a resilience biomarker for $\mathrm{MD}$ in patients with $\mathrm{CH}-\mathrm{C}$ (Fábregas et al., 2016). Accumulating evidence also supported an important role for decreased BDNF activity in the development of depression during IFN- $\alpha$ treatment (Lotrich et al., 2013). In summary, these evidences showed that the alterations in monoamine metabolism, impaired neuroendocrine function, and plasma biomarkers are the major aetiological pathways for IFN-induced neuropsychiatric symptoms in patients with $\mathrm{CH}-\mathrm{C}$, which may be helpful to improve the management of $\mathrm{HCV}$ patients receiving antiviral treatment and illuminate the IFN-induced depression.

Underlying mechanism between NAFLD and depression remains unknown. However, the production of pro-inflammatory cytokines, and the increased cortisol and epinephrine levels in patients with depression may be one plausible explanation for the link between depression and NAFLD (Maes et al., 1998; Miller et al., 2003; Penninx et al., 2003). Another potential explanation is the close correlation of NAFLD with obesity and diabetes mellitus, both of which have been strongly associated with depression symptoms (Lustman et al., 2000; Nouwen et al., 2010; Preiss et al., 2013; van Dooren et al., 2013; Muhlig et al., 2016). Nevertheless, this association cannot be fully explained by overweight status or poor adherence to therapy for diabetes alone, because anti-depressive treatment can improve insulin resistance and glycemic control (Lustman et al., 2000, 2005), which is independent of weight loss or adherence to diabetic treatment (Lustman et al., 1997, 1998; Okamura et al., 2000).

\section{IMPLICATIONS FOR THE CLINICAL MANAGEMENT OF PATIENTS WITH CLD}

Given the association of depression with severity of histological features of CLD, some investigators have focused on the influence of depression on the therapeutic effect of CLD. For example, Tomeno et al. (2015) compared the NAFLD clinical response within different stages of MDD, and suggested that NAFLD patients comorbid with MDD had poor response to the 48 weeks standard care for NAFLD. In particular, NAFLD patients with unstable MDD (not in full/partial remission) had severe resistance to the treatment (Tomeno et al., 2015). In addition to the therapeutic effect, Russ et al. (2015) performed a large sample meta-analysis to investigate the relationship between psychological distress (i.e., depression and anxiety) and liver disease (i.e., NAFLD and ALD) mortality using the 12-item GHQ. They found a significant increase in liver disease mortality with increase in GHQ score, which indicates that psychological distress is associated with mortality in CLD (Russ et al., 2015). Further research is needed to establish optimal management of depression in patients with NAFLD.

In addition to NAFLD, cirrhotic patients with depression experience worse health outcomes compared to matched patients without depression. In a previous study, Singh et al. (1997) assessed for orthotopic LT in depressed patients with decompensated liver disease of different aetiologies and found that these patients had an increased mortality at 100 days post-assessment compared to non-depressed patients. One possible explanation for this result is biological theories that focus on the effect of depression upon the immune system (dysregulated secretion of immunomodulatory cytokines and impaired lymphocyte function), ultimately may increase the propensity of patients with liver disease to decompensation (Koff et al., 1986; Irwin et al., 1987). Another explanation is psychological theories, which are based on the finding that depressed patients have high rates of noncompliance with medical regimens (DiMatteo et al., 2000).

Besides, as stated above, development of depression is the commonest reason for treatment discontinuation in patients with CH-C (Leutscher et al., 2010). Taken together, CLD or orthotopic LT patients with depression experience worse clinical outcomes, including a reduced quality of life and increased mortality, than those without.

\section{CONCLUSION}

This review summarizes the information on the prevalence and various risk factors of depression in patients with CLD, and shared biological pathways, as well as potentially molecular mechanisms for their association. Patients afflicted with CLD including $\mathrm{CH}-\mathrm{B}, \mathrm{CH}-\mathrm{C}, \mathrm{NAFLD}$, and ALD manifest different degrees of depression symptoms, which can adversely affect clinical care and patient outcomes. In addition, patients with cirrhosis had signs of psychological distress and depression in relation to the severity of liver disease (Bianchi et al., 2005). The majority of the cases remain under-diagnosed, which indicates that it is necessary to conduct better-developed studies to investigate the effect of depression screening on CLD management in this population. In previous studies, inconsistent findings regarding the prevalence and depression treatment outcomes in patients with CLD seem partly attributable to some limitations, including inconsistencies in the definition and measurement of depression, non-probability sampling and the absence of group matching. Further research is needed to identify depression in large population-based prospective cohorts of patients with CLD, comparing them with healthy controls, with patients with other long-term disorders, across the life course.

Relative to many studies of the prevalence of depression in patients with CLD, mechanistic studies of depression have been sparse. Generally, the main reasons include the following aspects: (i) the disease itself: the long-term pain caused by disease and 
treatment, sexual dysfunction and feeling of guilt, worry about disease progression, and fear of infecting family and friends, etc. (ii) social and economic pressure, including fundamental conditions for studying and working, social discrimination and high cost of medical treatment. (iii) Drug therapy: IFN has been widely used to treat viral hepatitis, in the meantime, depression is much more prevalent in CLD patients with IFN treatment than that in patients without it. However, these are the common characteristics of all chronic diseases, which cannot explain why CLD patients have a high prevalence of depression. For example, the consensus suggests that worsened depression symptoms are noted in patients with $\mathrm{CH}-\mathrm{C}$, but whether these symptoms consistently correlate with poor liver function is still not fully elucidated, and knowledge of mechanisms for depression in patients with $\mathrm{CH}-\mathrm{C}$ is limited. Additionally, it is still unknown whether depression could alter the liver tissue structurally and functionally. Further research needs to identify some biomarkers in both biological processes, to elucidate the

\section{REFERENCES}

Adam, R., Karam, V., Delvart, V., O’Grady, J., Mirza, D., Klempnauer, J., et al. (2012). Evolution of indications and results of liver transplantation in Europe. A report from the European Liver Transplant Registry (ELTR). J Hepatol. 57, 675-688. doi: 10.1016/j.jhep.2012.04.015

Alcocer-Gómez, E., de Miguel, M., Casas-Barquero, N., Nunez-Vasco, J., SanchezAlcazar, J. A., Fernandez-Rodriguez, A., et al. (2014). NLRP3 inflammasome is activated in mononuclear blood cells from patients with major depressive disorder. Brain Behav. Immun. 36, 111-117. doi: 10.1016/j.bbi.2013.10.017

Altindag, A., Cadirci, D., and Sirmatel, F. (2009). Depression and health related quality of life in non-cirrhotic chronic hepatitis B patients and hepatitis B carriers. Neurosciences 14, 56-59.

Angulo, P. (2002). Nonalcoholic fatty liver disease. N. Engl. J. Med. 346, 1221-1231. doi: 10.1056/NEJMra011775

Arslan, N., Buyukgebiz, B., Ozturk, Y., and Akay, A. P. (2003). Depression and anxiety in chronic hepatitis B: effect of hepatitis B virus infection on psychological state in childhood. Turk J. Pediatr. 45, 26-28.

Atesci, F. C., Cetin, B. C., Oguzhanoglu, N. K., Karadag, F., and Turgut, H. (2005). Psychiatric disorders and functioning in hepatitis B virus carriers. Psychosomatics 46, 142-147. doi: 10.1176/appi.psy.46.2.142

Bellentani, S., Tiribelli, C., Saccoccio, G., Sodde, M., Fratti, N., De Martin, C., et al. (1994). Prevalence of chronic liver disease in the general population of northern Italy: the Dionysos study. Hepatology 20, 1442-1449. doi: 10.1002/hep. 1840200611

Bianchi, G., Marchesini, G., Nicolino, F., Graziani, R., Sgarbi, D., Loguercio, C., et al. (2005). Psychological status and depression in patients with liver cirrhosis. Dig. Liver Dis. 37, 593-600. doi: 10.1016/j.dld.2005.01.020

Bonaccorso, S., Marino, V., Biondi, M., Grimaldi, F., Ippoliti, F., and Maes, M. (2002). Depression induced by treatment with interferon-alpha in patients affected by hepatitis C virus. J. Affect. Disord. 72, 237-241. doi: 10.1016/S01650327(02)00264- 1

Browning, J. D., Szczepaniak, L. S., Dobbins, R., Nuremberg, P., Horton, J. D., Cohen, J. C., et al. (2004). Prevalence of hepatic steatosis in an urban population in the United States: impact of ethnicity. Hepatology 40, 1387-1395. doi: 10.1002/hep.20466

Bull, S. J., Huezo-Diaz, P., Binder, E. B., Cubells, J. F., Ranjith, G., Maddock, C., et al. (2009). Functional polymorphisms in the interleukin-6 and serotonin transporter genes, and depression and fatigue induced by interferon-alpha and ribavirin treatment. Mol. Psychiatry 14, 1095-1104. doi: 10.1038/mp.2008.48

Bulloch, A., Lavorato, D., Williams, J., and Patten, S. (2012). Alcohol consumption and major depression in the general population: the critical importance of dependence. Depress. Anxiety 29, 1058-1064. doi: 10.1002/da.22001 potential biological correlations between depression and CLD. Large, well characterized cohorts are needed to test whether shared origins of depression and CLD exist at a genome-wide association significance level.

\section{AUTHOR CONTRIBUTIONS}

$\mathrm{XH}$ designed the topic and wrote the manuscript. XL helped to searched references. YY helped to revise the manuscript. All authors approved the final manuscript.

\section{ACKNOWLEDGMENT}

This work was supported by the National Natural Science Foundation of China (81571308) and Anhui Science and Technology Research Project (07020103142).

Burra, P., Senzolo, M., Adam, R., Delvart, V., Karam, V., Germani, G., et al. (2010). Liver transplantation for alcoholic liver disease in Europe: a study from the ELTR (European Liver Transplant Registry). Am. J. Transplant. 10, 138-148. doi: 10.1111/j.1600-6143.2009.02869.x

Capuron, L., Neurauter, G., Musselman, D. L., Lawson, D. H., Nemeroff, C. B., Fuchs, D., et al. (2003). Interferon-alpha-induced changes in tryptophan metabolism. relationship to depression and paroxetine treatment. Biol. Psychiatry 54, 906-914. doi: 10.1016/S0006-3223(03)00173-2

Capuron, L., Schroecksnadel, S., Feart, C., Aubert, A., Higueret, D., BarbergerGateau, P., et al. (2011). Chronic low-grade inflammation in elderly persons is associated with altered tryptophan and tyrosine metabolism: role in neuropsychiatric symptoms. Biol. Psychiatry 70, 175-182. doi: 10.1016/j. biopsych.2010.12.006

Cargiulo, T. (2007). Understanding the health impact of alcohol dependence. Am. J. Health Syst. Pharm. 64, S5-S11. doi: 10.2146/ajhp060647

Carta, M. G., Hardoy, M. C., Garofalo, A., Pisano, E., Nonnoi, V., Intilla, G., et al. (2007). Association of chronic hepatitis C with major depressive disorders: irrespective of interferon-alpha therapy. Clin. Pract. Epidemiol. Ment. Health 3:22. doi: 10.1186/1745-0179-3-22

Charlton, M. R., Burns, J. M., Pedersen, R. A., Watt, K. D., Heimbach, J. K., and Dierkhising, R. A. (2011). Frequency and outcomes of liver transplantation for nonalcoholic steatohepatitis in the United States. Gastroenterology 141, 1249-1253. doi: 10.1053/j.gastro.2011.06.061

Chitturi, S., Farrell, G. C., and George, J. (2004). Non-alcoholic steatohepatitis in the Asia-Pacific region: future shock? J. Gastroenterol. Hepatol. 19, 368-374. doi: 10.1111/j.1440-1746.2003.03252.x

Choi, A. J., and Ryter, S. W. (2014). Inflammasomes: molecular regulation and implications for metabolic and cognitive diseases. Mol. Cells 37, 441-448. doi: 10.14348/molcells.2014.0104

Clark, J. M., Brancati, F. L., and Diehl, A. M. (2002). Nonalcoholic fatty liver disease. Gastroenterology 122, 1649-1657. doi: 10.1053/gast.2002. 33573

Corruble, E., Barry, C., Varescon, I., Falissard, B., Castaing, D., and Samuel, D. (2011). Depressive symptoms predict long-term mortality after liver transplantation. J. Psychosom. Res. 71, 32-37. doi: 10.1016/j.jpsychores. 2010.12.008

Cozzolongo, R., Porcelli, P., Cariola, F., Giannuzzi, V., Lanzilotta, E., Gentile, M., et al. (2015). Serotonin gene polymorphisms and lifetime mood disorders in predicting interferon-induced depression in chronic hepatitis C. J. Affect. Disord. 183, 90-97. doi: 10.1016/j.jad.2015.04.056

Crum, R. M., Storr, C. L., and Chan, Y. F. (2005). Depression syndromes with risk of alcohol dependence in adulthood: a latent class analysis. Drug Alcohol Depend. 79, 71-81. doi: 10.1016/j.drugalcdep.2005.01.001 
Dan, A. A., Martin, L. M., Crone, C., Ong, J. P., Farmer, D. W., Wise, T., et al. (2006). Depression, anemia and health-related quality of life in chronic hepatitis C. J. Hepatol. 44, 491-498. doi: 10.1016/j.jhep.2005.11.046

Dew, M. A., Switzer, G. E., and DiMartini, A. F. (1998). Psychiatric morbidity and organ transplantation. Curr. Opin. Psychiatry 11, 621-626. doi: 10.1097/ 00001504-199811000-00005

DiMartini, A., Dew, M. A., Chaiffetz, D., Fitzgerald, M. G., Devera, M. E., and Fontes, P. (2011). Early trajectories of depressive symptoms after liver transplantation for alcoholic liver disease predicts long-term survival. Am. J. Transplant. 11, 1287-1295. doi: 10.1111/j.1600-6143.2011.03496.x

DiMatteo, M. R., Lepper, H. S., and Croghan, T. W. (2000). Depression is a risk factor for noncompliance with medical treatment: meta-analysis of the effects of anxiety and depression on patient adherence. Arch. Intern. Med. 160, 2101-2107. doi: 10.1001/archinte.160.14.2101

Dwight, M. M., Kowdley, K. V., Russo, J. E., Ciechanowski, P. S., Larson, A. M., and Katon, W. J. (2000). Depression, fatigue, and functional disability in patients with chronic hepatitis C. J. Psychosom. Res. 49, 311-317. doi: 10.1016/S00223999(00)00155-0

el-Serag, H. B., Kunik, M., Richardson, P., and Rabeneck, L. (2002). Psychiatric disorders among veterans with hepatitis C infection. Gastroenterology 123, 476-482. doi: 10.1053/gast.2002.34750

Elwing, J. E., Lustman, P. J., Wang, H. L., and Clouse, R. E. (2006). Depression, anxiety, and nonalcoholic steatohepatitis. Psychosom. Med. 68, 563-569. doi: 10.1097/01.psy.0000221276.17823.df

Erim, Y., Bottcher, M., Dahmen, U., Beck, O., Broelsch, C. E., and Helander, A. (2007). Urinary ethyl glucuronide testing detects alcohol consumption in alcoholic liver disease patients awaiting liver transplantation. Liver Transpl. 13, 757-761. doi: 10.1002/lt.21163

Ewusi-Mensah, I., Saunders, J. B., Wodak, A. D., Murray, R. M., and Williams, R. (1983). Psychiatric morbidity in patients with alcoholic liver disease. Br. Med. J. 287, 1417-1419. doi: 10.1136/bmj.287.6403.1417

Fábregas, B. C., Vieira, É. L., Moura, A. S., Carmo, R. A., Ávila, R. E., Abreu, M. N., et al. (2016). A Follow-up study of 50 chronic hepatitis $C$ patients: adiponectin as a resilience biomarker for major depression. Neuroimmunomodulation 23, 88-97. doi: 10.1159/000444531

Fontana, R. J., Schwartz, S. M., Gebremariam, A., Lok, A. S., and Moyer, C. A. (2002). Emotional distress during interferon-alpha-2B and ribavirin treatment of chronic hepatitis C. Psychosomatics 43, 378-385. doi: 10.1176/appi.psy.43. 5.378

Forton, D. M., Allsop, J. M., Main, J., Foster, G. R., Thomas, H. C., and TaylorRobinson, S. D. (2001). Evidence for a cerebral effect of the hepatitis C virus. Lancet 358, 38-39. doi: 10.1016/S0140-6736(00)05270-3

Galvao-de Almeida, A., Quarantini, L. C., Sampaio, A. S., Lyra, A. C., Parise, C. L., Parana, R., et al. (2011). Lack of association of indoleamine 2,3-dioxygenase polymorphisms with interferon-alpha-related depression in hepatitis C. Brain Behav. Immun. 25, 1491-1497. doi: 10.1016/j.bbi.2011.06.001

Gilman, S. E., and Abraham, H. D. (2001). A longitudinal study of the order of onset of alcohol dependence and major depression. Drug Alcohol. Depend. 63, 277-286. doi: 10.1016/S0376-8716(00)00216-7

Gochee, P. A., Powell, E. E., Purdie, D. M., Pandeya, N., Kelemen, L., Shorthouse, C., et al. (2004). Association between apolipoprotein E epsilon4 and neuropsychiatric symptoms during interferon alpha treatment for chronic hepatitis C. Psychosomatics 45, 49-57. doi: 10.1176/appi.psy.45.1.49

Gohier, B., Goeb, J. L., Rannou-Dubas, K., Fouchard, I., Cales, P., and Garre, J. B. (2003). Hepatitis C, alpha interferon, anxiety and depression disorders: a prospective study of 71 patients. World J. Biol. Psychiatry 4, 115-118. doi: 10.1080/15622970310029904

Golden, J., O’Dwyer, A. M., and Conroy, R. M. (2005). Depression and anxiety in patients with hepatitis C: prevalence, detection rates and risk factors. Gen. Hosp. Psychiatry 27, 431-438. doi: 10.1016/j.genhosppsych.2005.06.006

Grover, V. P., Pavese, N., Koh, S. B., Wylezinska, M., Saxby, B. K., Gerhard, A., et al. (2012). Cerebral microglial activation in patients with hepatitis C: in vivo evidence of neuroinflammation. J. Viral. Hepat. 19, e89-e96. doi: 10.1111/j. 1365-2893.2011.01510.x

Gutteling, J. J., de Man, R. A., van der Plas, S. M., Schalm, S. W., Busschbach, J. J., and Darlington, A. S. (2006). Determinants of quality of life in chronic liver patients. Aliment. Pharmacol. Ther. 23, 1629-1635. doi: 10.1111/j.1365-2036. 2006.02934.x
Hauser, P., Khosla, J., Aurora, H., Laurin, J., Kling, M. A., Hill, J., et al. (2002). A prospective study of the incidence and open-label treatment of interferoninduced major depressive disorder in patients with hepatitis C. Mol. Psychiatry 7, 942-947. doi: 10.1038/sj.mp.4001119

Henao-Mejia, J., Elinav, E., Jin, C., Hao, L., Mehal, W. Z., Strowig, T., et al. (2012). Inflammasome-mediated dysbiosis regulates progression of NAFLD and obesity. Nature 482, 179-185. doi: 10.1038/nature10809

Hensler, J. G. (2003). Regulation of 5-HT1A receptor function in brain following agonist or antidepressant administration. Life Sci. 72, 1665-1682. doi: 10.1016/ S0024-3205(02)02482-7

Hojat, M., Shapurian, R., and Mehryar, A. H. (1986). Dimensionality of the short form of the beck depression inventory: a study with Iranian college students. Psychol. Rep. 59, 1069-1070. doi: 10.2466/pr0.1986.59.3.1069

Horikawa, N., Yamazaki, T., Izumi, N., and Uchihara, M. (2003). Incidence and clinical course of major depression in patients with chronic hepatitis type $\mathrm{C}$ undergoing interferon-alpha therapy: a prospective study. Gen. Hosp. Psychiatry 25, 34-38. doi: 10.1016/S0163-8343(02)00239-6

Hui, J. M., Kench, J. G., Chitturi, S., Sud, A., Farrell, G. C., Byth, K., et al. (2003). Long-term outcomes of cirrhosis in nonalcoholic steatohepatitis compared with hepatitis C. Hepatology 38, 420-427. doi: 10.1053/jhep.2003.50320

Irwin, M., Daniels, M., Bloom, E. T., Smith, T. L., and Weiner, H. (1987). Life events, depressive symptoms, and immune function. Am. J. Psychiatry 144, 437-441. doi: 10.1176/ajp.144.4.437

Ismail, K., Winkley, K., Stahl, D., Chalder, T., and Edmonds, M. (2007). A cohort study of people with diabetes and their first foot ulcer: the role of depression on mortality. Diabetes Care 30, 1473-1479. doi: 10.2337/dc06-2313

Karayiannis, P., and Thomas, H. C. (2005). Is lamivudine a safe and effective therapy for patients with chronic hepatitis B and advanced liver disease? Nat. Clin. Pract. Gastroenterol. Hepatol. 2, 138-139. doi: 10.1038/ncpgasthep0118

Koff, W. C., Fann, A. V., Dunegan, M. A., and Lachman, L. B. (1986). Catecholamine-induced suppression of interleukin-1 production. Lymphokine Res. 5, 239-247.

Kraus, M. R., Al-Taie, O., Schafer, A., Pfersdorff, M., Lesch, K. P., and Scheurlen, M. (2007). Serotonin-1A receptor gene HTR1A variation predicts interferoninduced depression in chronic hepatitis C. Gastroenterology 132, 1279-1286. doi: 10.1053/j.gastro.2007.02.053

Kraus, M. R., Schafer, A., Csef, H., Faller, H., Mork, H., and Scheurlen, M. (2001). Compliance with therapy in patients with chronic hepatitis $\mathrm{C}$ : associations with psychiatric symptoms, interpersonal problems, and mode of acquisition. Dig. Dis. Sci. 46, 2060-2065. doi: 10.1023/A:1011973823032

Kunkel, E. J., Kim, J. S., Hann, H. W., Oyesanmi, O., Menefee, L. A., Field, H. L., et al. (2000). Depression in Korean immigrants with hepatitis B and related liver diseases. Psychosomatics 41, 472-480. doi: 10.1176/appi.psy.41.6.472

Lavanchy, D. (2004). Hepatitis B virus epidemiology, disease burden, treatment, and current and emerging prevention and control measures. J. Viral. Hepat. 11, 97-107. doi: 10.1046/j.1365-2893.2003.00487.x

Lavanchy, D. (2011). Evolving epidemiology of hepatitis C virus. Clin. Microbiol. Infect. 17, 107-115. doi: 10.1111/j.1469-0691.2010.03432.x

Lee, K., Otgonsuren, M., Younoszai, Z., Mir, H. M., and Younossi, Z. M. (2013). Association of chronic liver disease with depression: a population-based study. Psychosomatics 54, 52-59. doi: 10.1016/j.psym.2012.09.005

Leutscher, P. D., Lagging, M., Buhl, M. R., Pedersen, C., Norkrans, G., Langeland, N., et al. (2010). Evaluation of depression as a risk factor for treatment failure in chronic hepatitis C. Hepatology 52, 430-435. doi: 10.1002/ hep.23699

Li, R., Wang, X., Qin, T., Qu, R., and Ma, S. (2016). Apigenin ameliorates chronic mild stress-induced depressive behavior by inhibiting interleukin-1beta production and NLRP3 inflammasome activation in the rat brain. Behav. Brain Res. 296, 318-325. doi: 10.1016/j.bbr.2015.09.031

Liu, B., Xu, C., Wu, X., Liu, F., Du, Y., Sun, J., et al. (2015). Icariin exerts an antidepressant effect in an unpredictable chronic mild stress model of depression in rats and is associated with the regulation of hippocampal neuroinflammation. Neuroscience 294, 193-205. doi: 10.1016/j.neuroscience. 2015.02.053

Lok, A. S., van Leeuwen, D. J., Thomas, H. C., and Sherlock, S. (1985). Psychosocial impact of chronic infection with hepatitis $B$ virus on British patients. Genitourin. Med. 61, 279-282. doi: 10.1136/sti.61. 4.279 
Lopez-Figueroa, A. L., Norton, C. S., Lopez-Figueroa, M. O., Armellini-Dodel, D., Burke, S., Akil, H., et al. (2004). Serotonin 5-HT1A, 5-HT1B, and 5-HT2A receptor mRNA expression in subjects with major depression, bipolar disorder, and schizophrenia. Biol. Psychiatry 55, 225-233. doi: 10.1016/j.biopsych.2003. 09.017

Lotrich, F. E., Albusaysi, S., and Ferrell, R. E. (2013). Brain-derived neurotrophic factor serum levels and genotype: association with depression during interferon-alpha treatment. Neuropsychopharmacology 38, 985-995. doi: $10.1038 /$ npp.2012.263

Lotrich, F. E., Ferrell, R. E., Rabinovitz, M., and Pollock, B. G. (2009). Risk for depression during interferon-alpha treatment is affected by the serotonin transporter polymorphism. Biol. Psychiatry 65, 344-348. doi: 10.1016/ j.biopsych.2008.08.009

Lotrich, F. E., Ferrell, R. E., Rabinovitz, M., and Pollock, B. G. (2010). Labile anger during interferon alfa treatment is associated with a polymorphism in tumor necrosis factor alpha. Clin. Neuropharmacol. 33, 191-197. doi: 10.1097/WNF. 0b013e3181de8966

Lu, M., Yang, J. Z., Geng, F., Ding, J. H., and Hu, G. (2014). Iptakalim confers an antidepressant effect in a chronic mild stress model of depression through regulating neuro-inflammation and neurogenesis. Int. J. Neuropsychopharmacol. 17, 1501-1510. doi: 10.1017/S1461145714000285

Lustman, P. J., Anderson, R. J., Freedland, K. E., de Groot, M., Carney, R. M., and Clouse, R. E. (2000). Depression and poor glycemic control: a meta-analytic review of the literature. Diabetes Care 23, 934-942. doi: 10.2337/diacare.23. 7.934

Lustman, P. J., Clouse, R. E., Ciechanowski, P. S., Hirsch, I. B., and Freedland, K. E. (2005). Depression-related hyperglycemia in type 1 diabetes: a mediational approach. Psychosom. Med. 67, 195-199. doi: 10.1097/01.psy.0000155670. 88919.ad

Lustman, P. J., Griffith, L. S., Clouse, R. E., Freedland, K. E., Eisen, S. A., Rubin, E. H., et al. (1997). Effects of nortriptyline on depression and glycemic control in diabetes: results of a double-blind, placebo-controlled trial. Psychosom. Med. 59, 241-250. doi: 10.1097/00006842-199705000-00007

Lustman, P. J., Griffith, L. S., Freedland, K. E., Kissel, S. S., and Clouse, R. E. (1998). Cognitive behavior therapy for depression in type 2 diabetes mellitus. A randomized, controlled trial. Ann. Intern. Med. 129, 613-621. doi: 10.7326/ 0003-4819-129-8-199810150-00005

Maddock, C., Baita, A., Orru, M. G., Sitzia, R., Costa, A., Muntoni, E., et al. (2004). Psychopharmacological treatment of depression, anxiety, irritability and insomnia in patients receiving interferon-alpha: a prospective case series and a discussion of biological mechanisms. J. Psychopharmacol. 18, 41-46. doi: 10.1177/0269881104040230

Maes, M., Song, C., Lin, A., De Jongh, R., Van Gastel, A., Kenis, G., et al. (1998). The effects of psychological stress on humans: increased production of proinflammatory cytokines and a Th1-like response in stress-induced anxiety. Cytokine 10, 313-318. doi: 10.1006/cyto.1997.0290

Miller, G. E., Freedland, K. E., Carney, R. M., Stetler, C. A., and Banks, W. A. (2003). Pathways linking depression, adiposity, and inflammatory markers in healthy young adults. Brain Behav. Immun. 17, 276-285. doi: 10.1016/S0889-1591(03) 00057-6

Mirabdolhagh Hazaveh, M., Dormohammadi Toosi, T., Nasiri Toosi, M., Tavakoli, A., and Shahbazi, F. (2015). Prevalence and severity of depression in chronic viral hepatitis in Iran. Gastroenterol. Rep. 3, 234-237. doi: 10.1093/ gastro/gou091

Mohd Hanafiah, K., Groeger, J., Flaxman, A. D., and Wiersma, S. T. (2013). Global epidemiology of hepatitis $\mathrm{C}$ virus infection: new estimates of age-specific antibody to HCV seroprevalence. Hepatology 57, 1333-1342. doi: 10.1002/hep. 26141

Muhlig, Y., Antel, J., Focker, M., and Hebebrand, J. (2016). Are bidirectional associations of obesity and depression already apparent in childhood and adolescence as based on high-quality studies? A systematic review. Obes. Rev. 17, 235-249. doi: 10.1111/obr.12357

Mullish, B. H., Kabir, M. S., Thursz, M. R., and Dhar, A. (2014). Review article: depression and the use of antidepressants in patients with chronic liver disease or liver transplantation. Aliment. Pharmacol. Ther. 40, 880-892. doi: 10.1111/ apt. 12925

Naughton, M., Mulrooney, J. B., and Leonard, B. E. (2000). A review of the role of serotonin receptors in psychiatric disorders. Hum. Psychopharmacol.
15, 397-415. doi: 10.1002/1099-1077(200008)15:6<397::AID-HUP212<3.0. $\mathrm{CO} ; 2-\mathrm{L}$

Navines, R., Gomez, E., and Gasto, C. (2003). [The 5-HT1A receptors: from molecular biology to neuropsychiatric symptoms]. Actas Esp. Psiquiatr. 31, 272-283.

Negash, A. A., Ramos, H. J., Crochet, N., Lau, D. T., Doehle, B., Papic, N., et al. (2013). IL-1beta production through the NLRP3 inflammasome by hepatic macrophages links hepatitis $\mathrm{C}$ virus infection with liver inflammation and disease. PLoS Pathog. 9:e1003330. doi: 10.1371/journal.ppat. 1003330

Neurauter, G., Schrocksnadel, K., Scholl-Burgi, S., Sperner-Unterweger, B., Schubert, C., Ledochowski, M., et al. (2008). Chronic immune stimulation correlates with reduced phenylalanine turnover. Curr. Drug Metab. 9, 622-627. doi: $10.2174 / 138920008785821738$

Nouwen, A., Winkley, K., Twisk, J., Lloyd, C. E., Peyrot, M., Ismail, K., et al. (2010). Type 2 diabetes mellitus as a risk factor for the onset of depression: a systematic review and meta-analysis. Diabetologia 53, 2480-2486. doi: 10.1007/s00125010-1874-x

Okamura, F., Tashiro, A., Utumi, A., Imai, T., Suchi, T., Tamura, D., et al. (2000). Insulin resistance in patients with depression and its changes during the clinical course of depression: minimal model analysis. Metabolism 49, 1255-1260. doi: 10.1053/meta.2000.9515

O'Shea, R. S., Dasarathy, S., and McCullough, A. J. (2010). Alcoholic liver disease. Hepatology 51, 307-328. doi: 10.1002/hep.23258

Parkins, M. D., McNeil, S. A., and Laupland, K. B. (2009). Routine immunization of adults in Canada: Review of the epidemiology of vaccine-preventable diseases and current recommendations for primary prevention. Can. J. Infect. Dis. Med. Microbiol. 20, e81-e90. doi: 10.1155/2009/474035

Patten, S. B., Williams, J. V., Lavorato, D. H., Modgill, G., Jette, N., and Eliasziw, M. (2008). Major depression as a risk factor for chronic disease incidence: longitudinal analyses in a general population cohort. Gen. Hosp. Psychiatry 30, 407-413. doi: 10.1016/j.genhosppsych.2008.05.001

Penninx, B. W., Kritchevsky, S. B., Yaffe, K., Newman, A. B., Simonsick, E. M., Rubin, S., et al. (2003). Inflammatory markers and depressed mood in older persons: results from the health, aging and body composition study. Biol. Psychiatry 54, 566-572. doi: 10.1016/S0006-3223(02)01811-5

Pierucci-Lagha, A., Covault, J., Bonkovsky, H. L., Feinn, R., Abreu, C., Sterling, R. K., et al. (2010). A functional serotonin transporter gene polymorphism and depressive effects associated with interferon-alpha treatment. Psychosomatics 51, 137-148. doi: 10.1176/appi.psy.51.2.137

Popović, D., Ćulafić, D. M., Tepavčević, D. B., Kovačević, N. V., Špuran, M. M., Djuranović, S. P., et al. (2015). Assessment of depression and anxiety in patients with chronic liver disease. Vojnosanit. Pregl. 72, 414-420. doi: 10.2298/ VSP130904007P

Preiss, K., Brennan, L., and Clarke, D. (2013). A systematic review of variables associated with the relationship between obesity and depression. Obes. Rev. 14, 906-918. doi: 10.1111/obr.12052

Raison, C. L., Borisov, A. S., Broadwell, S. D., Capuron, L., Woolwine, B. J., Jacobson, I. M., et al. (2005a). Depression during pegylated interferon-alpha plus ribavirin therapy: prevalence and prediction. J. Clin. Psychiatry 66, 41-48.

Raison, C. L., Borisov, A. S., Woolwine, B. J., Massung, B., Vogt, G., and Miller, A. H. (2010). Interferon-alpha effects on diurnal hypothalamicpituitary-adrenal axis activity: relationship with proinflammatory cytokines and behavior. Mol. Psychiatry 15, 535-547. doi: 10.1038/mp.2008.58

Raison, C. L., Demetrashvili, M., Capuron, L., and Miller, A. H. (2005b). Neuropsychiatric adverse effects of interferon-alpha: recognition and management. CNS Drugs 19, 105-123.

Rice, J. P., Eickhoff, J., Agni, R., Ghufran, A., Brahmbhatt, R., and Lucey, M. R. (2013). Abusive drinking after liver transplantation is associated with allograft loss and advanced allograft fibrosis. Liver Transpl. 19, 1377-1386. doi: 10.1002/ lt. 23762

Rifai, M. A., and Sabouni, M. A. (2012). Utilizing genomic polymorphisms to personalize hepatitis C therapies. Curr. Opin. Organ. Transplant. 17, 198-203. doi: 10.1097/MOT.0b013e328351093b

Russ, T. C., Kivimaki, M., Morling, J. R., Starr, J. M., Stamatakis, E., and Batty, G. D. (2015). Association between psychological distress and liver disease mortality: a meta-analysis of individual study participants. Gastroenterology 148, 958-966.e4. doi: 10.1053/j.gastro.2015.02.004 
Sakhuja, P. (2014). Pathology of alcoholic liver disease, can it be differentiated from nonalcoholic steatohepatitis? World J. Gastroenterol. 20, 16474-16479. doi: 10.3748/wjg.v20.i44.16474

Schaefer, M., Capuron, L., Friebe, A., Diez-Quevedo, C., Robaeys, G., Neri, S., et al. (2012). Hepatitis C infection, antiviral treatment and mental health: a European expert consensus statement. J. Hepatol. 57, 1379-1390. doi: 10.1016/j.jhep.2012. 07.037

Schaefer, M., Engelbrecht, M. A., Gut, O., Fiebich, B. L., Bauer, J., Schmidt, F., et al. (2002). Interferon alpha (IFNalpha) and psychiatric syndromes: a review. Prog. Neuropsychopharmacol. Biol. Psychiatry 26, 731-746.

Schaefer, M., Hinzpeter, A., Mohmand, A., Janssen, G., Pich, M., Schwaiger, M., et al. (2007). Hepatitis C treatment in "difficult-to-treat" psychiatric patients with pegylated interferon-alpha and ribavirin: response and psychiatric side effects. Hepatology 46, 991-998. doi: 10.1002/hep.21791

Schaefer, M., Schmidt, F., Folwaczny, C., Lorenz, R., Martin, G., Schindlbeck, N., et al. (2003). Adherence and mental side effects during hepatitis $\mathrm{C}$ treatment with interferon alfa and ribavirin in psychiatric risk groups. Hepatology 37, 443-451. doi: 10.1053/jhep.2003.50031

Schafer, A., Scheurlen, M., Felten, M., and Kraus, M. R. (2005). Physician-patient relationship and disclosure behaviour in chronic hepatitis $\mathrm{C}$ in a group of German outpatients. Eur. J. Gastroenterol. Hepatol. 17, 1387-1394. doi: 10.1097/ 00042737-200512000-00019

Seitz, H. K., and Stickel, F. (2007). Alcoholic liver disease in the elderly. Clin. Geriatr. Med. 23, 905-921,viii. doi: 10.1016/j.cger.2007.06.010

Singal, A. K., Guturu, P., Hmoud, B., Kuo, Y. F., Salameh, H., and Wiesner, R. H. (2013). Evolving frequency and outcomes of liver transplantation based on etiology of liver disease. Transplantation 95, 755-760. doi: 10.1097/TP. 0b013e31827afb3a

Singh, N., Gayowski, T., Wagener, M. M., and Marino, I. R. (1997). Depression in patients with cirrhosis. Impact on outcome. Dig. Dis. Sci. 42, 1421-1427. doi: 10.1023/A:1018898106656

Smith, A. K., Simon, J. S., Gustafson, E. L., Noviello, S., Cubells, J. F., Epstein, M. P., et al. (2012). Association of a polymorphism in the indoleamine- 2,3dioxygenase gene and interferon-alpha-induced depression in patients with chronic hepatitis C. Mol. Psychiatry 17, 781-789. doi: 10.1038/mp.2011.67

Stepanova, M., Wai, H., Saab, S., Mishra, A., Venkatesan, C., and Younossi, Z. M. (2014). The portrait of an adult liver transplant recipient in the United States from 1987 to 2013. JAMA Intern. Med. 174, 1407-1409. doi: 10.1001/ jamainternmed.2014.2903

Su, K. P., Huang, S. Y., Peng, C. Y., Lai, H. C., Huang, C. L., Chen, Y. C., et al. (2010). Phospholipase A2 and cyclooxygenase 2 genes influence the risk of interferon-alpha-induced depression by regulating polyunsaturated fatty acids levels. Biol. Psychiatry 67, 550-557. doi: 10.1016/j.biopsych.2009.11.005

Szabo, G., and Petrasek, J. (2015). Inflammasome activation and function in liver disease. Nat. Rev. Gastroenterol. Hepatol. 12, 387-400. doi: 10.1038/nrgastro. 2015.94

Targher, G., Bertolini, L., Padovani, R., Rodella, S., Tessari, R., Zenari, L., et al. (2007). Prevalence of nonalcoholic fatty liver disease and its association with cardiovascular disease among type 2 diabetic patients. Diabetes Care 30, 1212-1218. doi: 10.2337/dc06-2247

Tomeno, W., Kawashima, K., Yoneda, M., Saito, S., Ogawa, Y., Honda, Y., et al. (2015). Non-alcoholic fatty liver disease comorbid with major depressive disorder: the pathological features and poor therapeutic efficacy. J. Gastroenterol. Hepatol. 30, 1009-1014. doi: 10.1111/jgh.12897

Valentine, A. D., and Meyers, C. A. (2005). Neurobehavioral effects of interferon therapy. Curr. Psychiatry Rep. 7, 391-395. doi: 10.1007/s11920-005-0042-3

van Dooren, F. E., Nefs, G., Schram, M. T., Verhey, F. R., Denollet, J., and Pouwer, F. (2013). Depression and risk of mortality in people with diabetes mellitus: a systematic review and meta-analysis. PLoS ONE 8:e57058. doi: 10.1371/journal.pone.0057058
Wanless, I. R., and Lentz, J. S. (1990). Fatty liver hepatitis (steatohepatitis) and obesity: an autopsy study with analysis of risk factors. Hepatology 12, 1106-1110. doi: 10.1002/hep.1840120505

Weinstein, A. A., Kallman Price, J., Stepanova, M., Poms, L. W., Fang, Y., Moon, J., et al. (2011). Depression in patients with nonalcoholic fatty liver disease and chronic viral hepatitis B and C. Psychosomatics 52, 127-132. doi: 10.1016/j. psym.2010.12.019

Weissenborn, K., Ennen, J. C., Bokemeyer, M., Ahl, B., Wurster, U., Tillmann, H., et al. (2006). Monoaminergic neurotransmission is altered in hepatitis C virus infected patients with chronic fatigue and cognitive impairment. Gut 55, 1624-1630. doi: 10.1136/gut.2005.080267

Wichers, M. C., Kenis, G., Koek, G. H., Robaeys, G., Nicolson, N. A., and Maes, M. (2007). Interferon-alpha-induced depressive symptoms are related to changes in the cytokine network but not to cortisol. J. Psychosom. Res. 62, 207-214. doi: 10.1016/j.jpsychores.2006.09.007

Widner, B., Ledochowski, M., and Fuchs, D. (2000). Interferon-gammainduced tryptophan degradation: neuropsychiatric and immunological consequences. Curr. Drug Metab. 1, 193-204. doi: 10.2174/138920000 3339063

Wild, S., Roglic, G., Green, A., Sicree, R., and King, H. (2004). Global prevalence of diabetes: estimates for the year 2000 and projections for 2030. Diabetes Care 27, 1047-1053. doi: 10.2337/diacare.27.5.1047

Wree, A., Eguchi, A., McGeough, M. D., Pena, C. A., Johnson, C. D., Canbay, A., et al. (2014a). NLRP3 inflammasome activation results in hepatocyte pyroptosis, liver inflammation, and fibrosis in mice. Hepatology 59, 898-910. doi: 10.1002/ hep. 26592

Wree, A., McGeough, M. D., Pena, C. A., Schlattjan, M., Li, H., Inzaugarat, M. E., et al. (2014b). NLRP3 inflammasome activation is required for fibrosis development in NAFLD. J. Mol. Med. 92, 1069-1082. doi: 10.1007/s00109-0141170-1

Xue, J., Li, H., Deng, X., Ma, Z., Fu, Q., and Ma, S. (2015). L-Menthone confers antidepressant-like effects in an unpredictable chronic mild stress mouse model via NLRP3 inflammasome-mediated inflammatory cytokines and central neurotransmitters. Pharmacol. Biochem. Behav. 134, 42-48. doi: 10.1016/j.pbb. 2015.04.014

Youssef, N. A., Abdelmalek, M. F., Binks, M., Guy, C. D., Omenetti, A., Smith, A. D., et al. (2013). Associations of depression, anxiety and antidepressants with histological severity of nonalcoholic fatty liver disease. Liver Int. 33, 1062-1070. doi: 10.1111/liv.12165

Youssef, W., and McCullough, A. J. (2002). Diabetes mellitus, obesity, and hepatic steatosis. Semin Gastrointest Dis 13, 17-30.

Zhang, Y., Liu, L., Liu, Y. Z., Shen, X. L., Wu, T. Y., Zhang, T., et al. (2015). NLRP3 inflammasome mediates chronic mild stress-induced depression in mice via neuroinflammation. Int. J. Neuropsychopharmacol. 18:pyv006. doi: 10.1093/ijnp/pyv006

Zhang, Y., Liu, L., Peng, Y. L., Liu, Y. Z., Wu, T. Y., Shen, X. L., et al. (2014). Involvement of inflammasome activation in lipopolysaccharide-induced mice depressive-like behaviors. CNS Neurosci. Ther. 20, 119-124. doi: 10.1111/cns. 12170

Conflict of Interest Statement: The authors declare that the research was conducted in the absence of any commercial or financial relationships that could be construed as a potential conflict of interest.

Copyright (C) 2017 Huang, Liu and Yu. This is an open-access article distributed under the terms of the Creative Commons Attribution License (CC BY). The use, distribution or reproduction in other forums is permitted, provided the original author(s) or licensor are credited and that the original publication in this journal is cited, in accordance with accepted academic practice. No use, distribution or reproduction is permitted which does not comply with these terms. 